\title{
The Strongylidae belonging to Strongylus genus in horses from southeastern Poland
}

\author{
M. B. Studzińska • K. Tomczuk • M. Demkowska-Kutrzepa • \\ K. Szczepaniak
}

Received: 18 May 2012 / Accepted: 10 August 2012 /Published online: 8 September 2012

(C) The Author(s) 2012. This article is published with open access at Springerlink.com

\begin{abstract}
Postmortem parasitic examinations of the large intestines of 725 slaughtered horses from individual farmers in southeastern Poland were carried out. The examinations were carried out monthly since February 2006 until January 2007 (except for August 2007 because of a technological stoppage in the slaughterhouse). The examinations included the intensiveness and extensiveness of the infestation of the Strongylidae belonging to the Strongylus genus. The Strongylidae were found in $26.5 \%$ of the examined horses. Strongylus vulgaris was the most dominant nematode and had a $22.8 \%$ prevalence, Strongylus edentatus was carried by $18.3 \%$ of the horses. Strongylus equinus was identified only in $1.7 \%$ of the examined horses. Our findings revealed that combined infestation of $S$. vulgaris and S. edentatus occurred in $100(52.1 \%)$ of the 725 horses infected by the Strongylidae. The present results indicate that the lowest prevalence of strongyle species except for S. equinus was found in January, February, and March. However, it is difficult to draw a conclusion because of an extremely low extensiveness of infestation. The results indicate that the prevalence of the Strongylidae in horses from southeastern Poland is limited.
\end{abstract}

\section{Introduction}

Reports of other authors and our earlier coproscopic and postmortem examinations revealed that the occurrence of nematode parasites from the family Strongylidae is common in horses from both studs and individual farms in southeastern

M. B. Studzińska $(\bowtie) \cdot$ K. Tomczuk $\cdot$ M. Demkowska-Kutrzepa $\cdot$

K. Szczepaniak

Department of Parasitology and Invasive Diseases, Faculty

of Veterinary Medicine, University of Life Sciences in Lublin,

Akademicka 12,

20-033 Lublin, Poland

e-mail: maria.studzinska@up.lublin.pl
Poland (Gawor 1995, 2000, 2002; Gawor et al. 2006; Gundłach et al. 2004; Kornaś et al. 2004a; Kornaś et al. 2004b; Sobieszewski 1967). Customarily, the Strongylidae fall into the subfamily Strongylinae (15 species organized in five genera: Strongylus, Triodontophorus, Bidentostomum, Craterostomum, and Oesophagodontus, grouped as large strongyle species) and Cyathostominae (52 species organized in 14 genera including Cyathostomum, Coronocyclus, Cylicodontophorus, Cylicocyclus, Cylicostephanus, Poteriostomum, Gyalocephalus, grouped as small strongyle species) (Lichtenfels et al. 2003). They differ morphologically and reveal various developmental cycles, localizations, feeding manner, pathogenicity of mature and larva forms, and resistance to drugs. In spite of numerous reports on horse parasites, detailed data including nematode parasites belonging to the genus Strongylus considered as especially pathogenic are scarce.

It should be stressed that in the case of the genus Strongylus, both mature and larva forms are pathogenic (Gundłach and Sadzikowski 2004; Schnieder 2006) among which Strongylus vulgaris larvae migrating in the circulatory system are regarded as the most pathogenic. These larvae produce adhering to wall clots and aneurysms, and emboli in the small arterioles. The larva Strongylus edentatus which migrates under the parietal peritoneum may cause peritoneum inflammation. It is believed that the larvae migrating through the liver may damage this organ. Similarly, Strongylus equinus larvae may also damage the liver and then cause inflammation of the pancreas. Mature nematodes may sponge and cause lesions in the large intestine by fixating with large mouth capsules to the mucous membranes. The nematodes fitted with cutting components produce incisions in the mucous membranes and take up the blood, which may lead to anemia in the case of a great number of larvae. The above findings are supported by our observation.

The manner of feeding of strongylids from the genus Strongylus seems to differ from that of small strongyle 
species belonging to the subfamily Cyathostominae (Gawor 2006). The small strongyle species harbor in the contents of large intestine and localize in its parts depending on the species. These nematodes feed mainly on protozoa of the occupied part of the intestine and also small plant elements. Thus, mature small strongyles do not damage significantly the mucosal membrane of the intestine but may impair digestion by changing the population of protozoa.

The aim of the present studies was to provide additional information involving the infestation of strongyles from the genus Strongylus in horses.

\section{Material and methods}

The large intestines collected from 725 slaughter horses from individual farms in southeastern Poland were autopsied for parasitic examinations. The examinations were carried out monthly since February 2006 until January 2007 (except for August 2007 because of a technological stoppage in the slaughterhouse). At necropsy, care was taken on localization of strongyles and lesions caused by the nematodes. The nematodes isolated from the intestine were differentiated on the basis of detailed anatomical structure. The number of strongyles belonging to the genus Strongylus was evaluated.

\section{Results}

The strongyles from the genus Strongylus was evidenced in $26.5 \%$ of examined horses (Table 1). Further, it was found that $S$. vulgaris was the dominant strongyle in southeastern
Poland with a $22.8 \%$ prevalence whereas the extensiveness of $S$. equinus infestation was markedly lower $(1.7 \%)$. S. edentatus was found in $18.3 \%$ of examined horses (Figs. 1 and 2). The intensiveness of strongyle infestation from the genus Strongylus was low with mean values of 27.2, 12.3, and $7.1 \%$ for $S$. vulgaris, S. edentatus, and S. equinus, respectively.

A majority of strongyles belonging to the genus Strongylus was attached to the mucosal membrane of the cecum or abdominal stratum of the large colon (Figs. 3 and 4). However, in spite of a relatively low intensiveness, changes in mucosal membranes of several horses were extensive. Numerous hyperemia focuses accompanied by mucosal membrane swellings and extravasations at the site of the parasite location were observed.

The yearly seasonal distribution of the infestation of strongyles belonging to the genus Strongylus was shown in Table 1. Seasonal changes in extensiveness of infestation were noted, and the lowest one was found in winter.

Table 2 shows a prevalence of single or multispecies strongyles in examined horses. A dominant combined infestation of S. vulgaris and S. edentatus was found in 100 of 725 examined horses ( $52.1 \%$ of animals infected with strongyles).

\section{Discussion}

There are not many publications considering the genus Strongylus because intravital determination of species belonging of the nematode parasites by coproscopy examination is difficult and in some cases impossible. This determination needs comprehensive knowledge and careful morphometric analysis of larvae from fecal cultures or the use of modern
Table 1 Time-dependent distribution of infestation of strongyles belonging to the genus Strongylus

\begin{tabular}{|c|c|c|c|c|c|}
\hline \multirow[t]{2}{*}{ Date } & \multirow{2}{*}{$\begin{array}{l}\text { Number of examined } \\
\text { horses }\end{array}$} & \multicolumn{4}{|c|}{ Number and percentage (\%) of infected horses } \\
\hline & & $\begin{array}{l}\text { Strongyles from the } \\
\text { genus Strongylus }\end{array}$ & $\begin{array}{l}\text { Strongylus } \\
\text { vulgaris }\end{array}$ & $\begin{array}{l}\text { Strongylus } \\
\text { edentatus }\end{array}$ & $\begin{array}{l}\text { Strongylus } \\
\text { equinus }\end{array}$ \\
\hline February 2006 & 35 & $4(11.4)$ & $3(8.6)$ & $2(5.7)$ & 0 \\
\hline March 2006 & 40 & $2(5.0)$ & $2(5.0)$ & $2(5.0)$ & 0 \\
\hline April 2006 & 85 & $19(22.4)$ & $17(20.0)$ & $11(12.9)$ & $2(2.4)$ \\
\hline May 2006 & 97 & $25(25.8)$ & $23(23.7)$ & $17(17.5)$ & $1(1.0)$ \\
\hline June 2006 & 56 & $19(33.9)$ & $18(32.1)$ & $12(21.4)$ & 0 \\
\hline July 2006 & 78 & $25(32.1)$ & $21(26.9)$ & $16(20.5)$ & 0 \\
\hline August 2006 & Not examined & & & & \\
\hline September 2006 & 120 & $28(23.3)$ & $21(17.5)$ & $19(15.8)$ & 0 \\
\hline October 2006 & 64 & $23(35.9)$ & $21(32.8)$ & $17(26.6)$ & 0 \\
\hline November 2006 & 72 & $20(27.8)$ & $16(22.2)$ & $14(19.4)$ & $4(5.6)$ \\
\hline December 2006 & 65 & $19(29.2)$ & $16(24.6)$ & $18(27.7)$ & $3(4.61)$ \\
\hline January 2007 & 55 & $8(14.5)$ & $8(14.5)$ & $5(9.1)$ & $2(3.6)$ \\
\hline Total & 725 & $192(26.5)$ & $165(22.8)$ & $133(18.4)$ & $12(1.7)$ \\
\hline
\end{tabular}




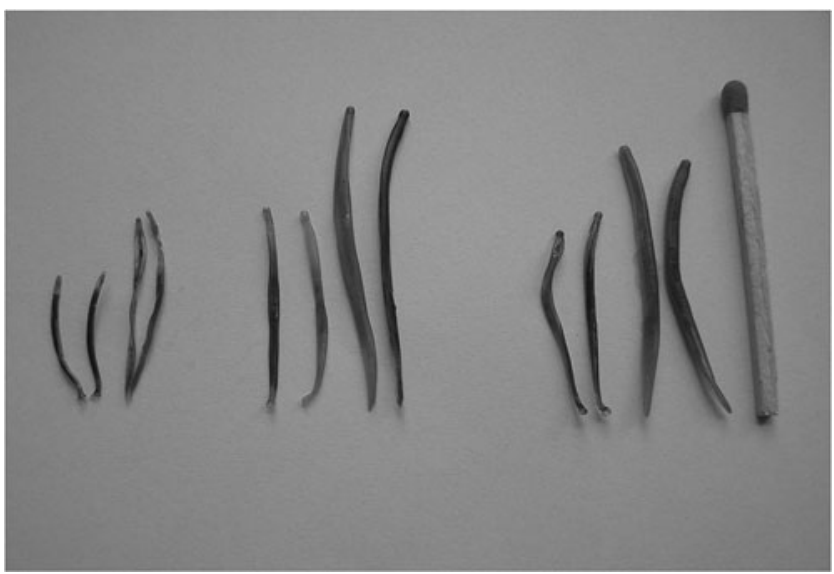

Fig. 1 Strongylidae from the genus Strongylus: S. vulgaris, S. equinus, and $S$. edentatus

molecular methods (Gundłach and Sadzikowski 2004; Nielsen et al. 2008; Schnieder 2006; Traversa et al. 2007).

Not many postmortem examinations of horses focused on prevalence of individual species of strongyles belonging to the genus Strongylus performed in Poland indicate $S$. vulgaris as the dominant species. In the present studies involving a large number of animals, the extensiveness of this nematode infestation was $22.8 \%$ making it markedly lower in comparison to a 60 to $78 \%$ prevalence reported by others ((Gawor 1995; Gawor et al. 2006; Gundłach et al. 2004; Sobieszewski 1967). The extensiveness of $S$. edentatus infestation amounted to $18.3 \%$ and was similar to that (20 to $22 \%$ ) evidenced earlier in the Lublin Region (Gundłach et al. 2004; Sobieszewski 1967). However, Gawor 1995 found twice higher prevalence amounting to $40 \%$ in the 1990 s, but more current studies failed to evidence the nematodes; this controversy may result from the procedure used by the authors (Gawor et al. 2006). Current studies indicating a low prevalence of $S$. equinus (extensiveness, $1.7 \%$ ) confirm our earlier observations which failed to find the nematodes in horses from the Lublin Region (Gundlach et al. 2004) and are in contrast to other reports showing $S$. equines in 14 to

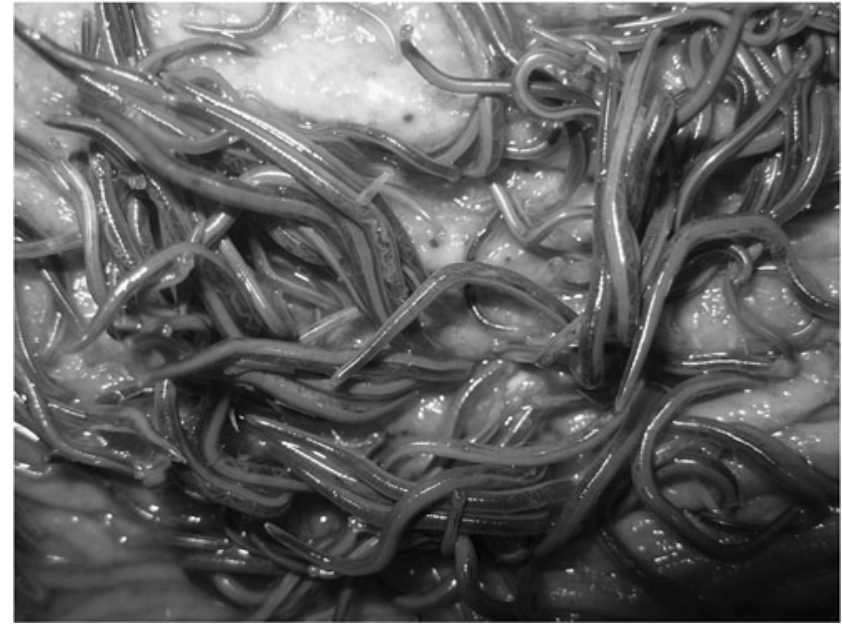

Fig. 3 Strongylidae on the mucosal membrane of the cecum

$28 \%$ of horses (Gawor 1995; Gawor et al. 2006; Sobieszewski 1967).

Comparison of the worldwide distribution of individual strongyles species belonging to strongyles shows $S$. vulgaris as the dominant species with a prevalence amounting up to 88 \% (Atlas et al. 2007; Boxell et al. 2003; English 1979; Königová et al. 2001; Kuzmina et al. 2005; Lyons et al. 2006; Pereira and Vianna 2006; Uslu and Guclu 2007). Other species dominated only in few countries, for example $S$. edentatus in Island (Eydal and Gunnarsson 1994) and S. equinus in Greece (Theodoridis et al. 1999). However, it should be stressed that the results were obtained using various intravital and postmortem procedures. The examinations included not the same numbers of horses, kept in various systems, used in different ways, and were controlled or not controlled. Moreover, the years in which the examinations were carried out may affect significantly the results, because the strategy of parasite control in horses has been changing since the 1990s.

The extensiveness of infestation of individual strongyles species belonging to the genus Strongylus found in the present studies seems to support an opinion suggesting a
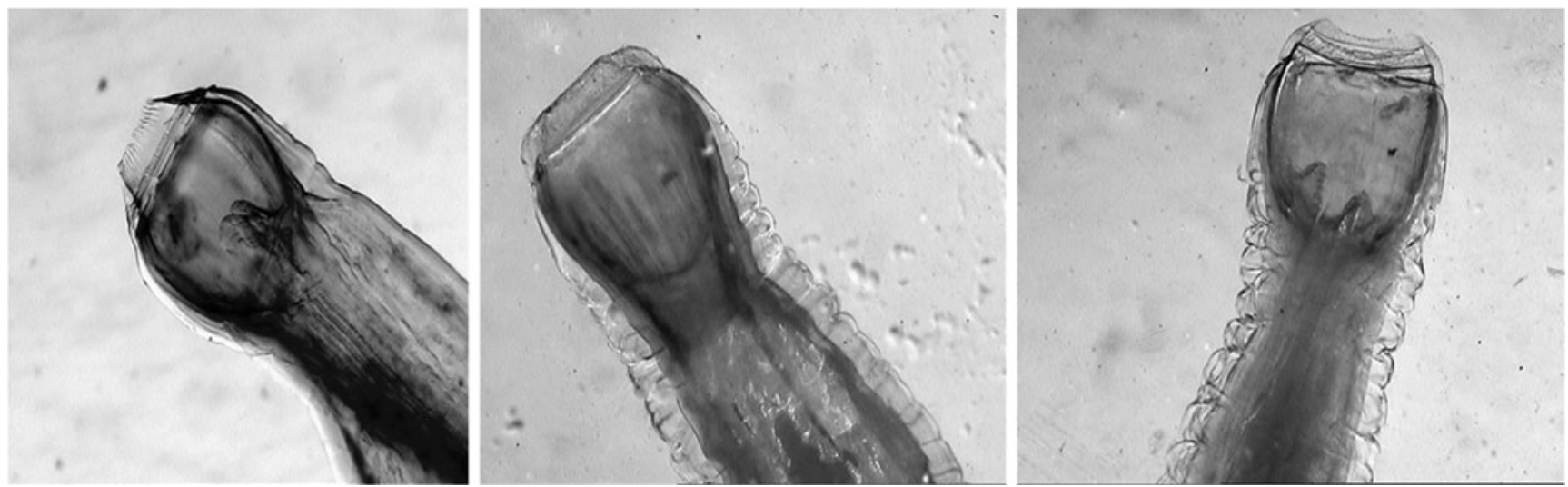

Fig. 2 The buccal cavity of large strongyles from the genus Strongylus: S. vulgaris, S. edentatus, and S. equinus 


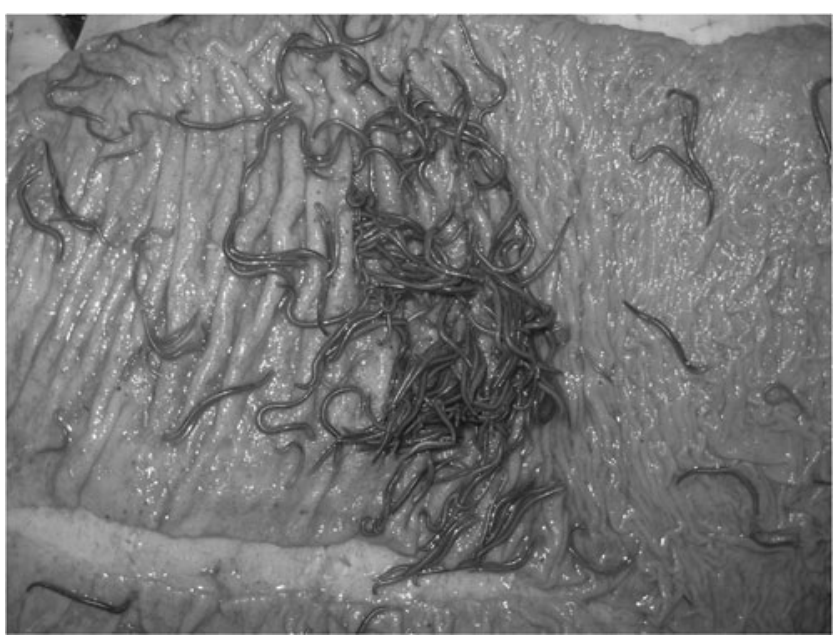

Fig. 4 Strongylidae on the mucosal membrane of the abdominal stratum of the large colon

lowering prevalence in numerous regions of the world. This view is reliably confirmed by the data reported in Germany where $S$. vulgaris and S. edentatus were frequently found until recently whereas, now, these nematode parasites occur rarely or are not found in many regions (Schnieder 2006). Similar results were evidenced in Australia indicating a dramatic decrease in prevalence of the genus Strongylus during the last decades (Boxell et al. 2003; Bucknell et al. 1995; English 1979). The widespread infestation of strongyles is affected by several variables including the occurrence of drug-resistant strains (Gawor 2006). The lack of drug-resistant strains is a result of long life cycles of these nematode parasites and limited contact of mature nematodes with anthelmintics. The regular use of antiparasitic compounds in horses eliminates these nematodes from infested areas.

The present results indicate that the lowest prevalence of strongyle species, except for S. equinus, was found in January, February, and March. However, it is difficult to draw a conclusion because of an extremely low extensiveness of infestation. Similar relationships were reported by others (Chapman et al. 2003). Changes in yearly infestation extensiveness result mainly from the life cycles of strongyles for which the prepatent period may last even a few months (Gundłach and Sadzikowski 2004; Schnieder 2006). Thus, the horses infected on pastures excreted the eggs of strongyles till the next year.

The present results considering the structure of infestation in examined horses with single- or multispecies nematodes belonging to Strongylus species seem interesting. These findings indicated that a combined infestation with $S$. vulgaris and S. edentatus found in $52.1 \%$ of horses infected with large strongyles was the most frequent. Infestations with one species including S. vulgaris (55 horses, $28.7 \%$ ) and S. edentatus ( 25 horses, $13 \%$ ) were observed less frequently. This tendency persisted for a majority of months in the year.

Results of others (Boxell et al. 2003; Bucknell et al. 1995; English 1979; Schnieder 2006) and our data confirm the view that strongyles belonging to the genus Strongylus will occur less frequently in horses. However, these nematode parasites should arouse the veterinary surgeons' interest. Horses severely infected with the nematode parasites exhibit lack of appetite, disorders in the gastrointestinal functioning, and developing

Table 2 Infestation of single- and multispecies strongyles belonging to the genus Strongylus in examined horses

\begin{tabular}{|c|c|c|c|c|c|c|c|c|}
\hline \multirow[t]{3}{*}{ Date } & \multirow[t]{3}{*}{ Number of horses } & \multicolumn{7}{|c|}{ Number and percentage (\%) of infected horses } \\
\hline & & \multicolumn{3}{|c|}{ Single-species } & \multicolumn{4}{|l|}{ Multispecies } \\
\hline & & $\begin{array}{l}\text { Strongylus } \\
\text { vulgaris }\end{array}$ & $\begin{array}{l}\text { Strongylus } \\
\text { edentatus }\end{array}$ & $\begin{array}{l}\text { Strongylus } \\
\text { equinus }\end{array}$ & $\begin{array}{l}\text { S. vulgaris } \\
\text { S. edentatus }\end{array}$ & $\begin{array}{l}\text { S. vulgaris } \\
\text { S. equinus }\end{array}$ & $\begin{array}{l}\text { S. edentatus } \\
\text { S. equinus }\end{array}$ & $\begin{array}{l}\text { S. vulgaris } \\
\text { S. edentatus } \\
\text { S. equinus }\end{array}$ \\
\hline February 2006 & 4 & $2(50.0)$ & $1(25.0)$ & 0 & $1(25.0)$ & 0 & 0 & 0 \\
\hline March 2006 & 2 & 0 & 0 & 0 & $2(100)$ & 0 & 0 & 0 \\
\hline April 2006 & 19 & $7(36.8)$ & $1(5.3)$ & 0 & $9(47.3)$ & $1(5.3)$ & $1(5.3)$ & 0 \\
\hline May 2006 & 25 & $8(32.0)$ & $2(8.0)$ & 0 & $14(56.0)$ & 0 & 0 & $1(4.0)$ \\
\hline June 2006 & 19 & $7(36.8)$ & $1(5.3)$ & 0 & $11(57.9)$ & 0 & 0 & 0 \\
\hline July 2006 & 25 & $9(36.0)$ & $4(16.0)$ & 0 & $12(48.0)$ & 0 & 0 & 0 \\
\hline August 2006 & Not examined & & & & & & & \\
\hline September 2006 & 28 & $9(32.1)$ & $7(25.0)$ & 0 & $12(42.9)$ & 0 & 0 & 0 \\
\hline October 2006 & 23 & $6(26.1)$ & $3(13.0)$ & 0 & $14(60.9)$ & 0 & 0 & 0 \\
\hline November 2006 & 20 & $5(25.0)$ & $3(15.0)$ & $1(5.0)$ & $8(40.0)$ & 0 & 0 & $3(15.0)$ \\
\hline December 2006 & 19 & $1(5.3)$ & $3(15.8)$ & 0 & $12(63.2)$ & 0 & 0 & $3(15.8)$ \\
\hline January 2007 & 8 & $1(12.5)$ & 0 & 0 & $5(62.5)$ & $2(25.0)$ & 0 & 0 \\
\hline Total & 192 & $55(28.7)$ & $25(13.0)$ & $1(0.5)$ & $100(52.1)$ & $3(1.6)$ & $1(0.5)$ & $7(3.7)$ \\
\hline
\end{tabular}


emaciation. The large strongyles are a significant reason for colic caused mainly by migrating larvae, especially $S$. vulgaris and also mature parasites. It should be stressed that in the case of nonintensive infestations, sometimes without signs, these parasites decrease the performance and efficiency of horses.

Open Access This article is distributed under the terms of the Creative Commons Attribution License which permits any use, distribution, and reproduction in any medium, provided the original author (s) and the source are credited.

\section{References}

Atlas MG, Gokcen A, Sevgili M (2007) Prevalence of helminth species in Arabian horses. Indian Vet J 84:1093-1094

Boxell AC, Gibson KT, Hobbs RP, Thompson RCA (2003) Occurrence of gastrointestinal parasites in horses in metropolitan Perth, Western Australia. Aust Vet J 82:91-95

Bucknell DG, Gasser RB, Beveridge I (1995) The prevalence and epidemiology of gastrointestinal parasites of horses in Victoria, Australia. Int J Parasitol 25:711-724

Chapman MR, French DD, Klei TR (2003) Prevalence of strongyle nematodes in naturally infected ponies of different ages and during different seasons of the year in Louisiana. J Parasitol 89:309-314

English AW (1979) The epidemiology of equine strongylosis in southern Queensland 3. Seasonal variation in arterial populations of Strongylus vulgaris, and the prevalence of some helminthes. J Aust Vet Assoc 55:310-314

Eydal M, Gunnarsson E (1994) Helminth infections in a group of Icelandic horses with little exposure to anthelmintics. Icel Agr Sci 8:85-91

Gawor J (1995) The prevalence and abundance of internal parasites in working horses autopsied in Poland. Vet Parasitol 58:99-108

Gawor J (2000) Occurrence of Strongylidae (Nematoda: Strongyloidea) in Polish horses "tarpans" from Popielno Reserve. Wiad Parazytol 46:87-92

Gawor J (2002) Prevalence of intestinal parasites in riding horses. Medycyna Wet 58:148-150

Gawor J (2006) Research and treatment of small strongyle (Cyathostominae) in horses. Postdoctoral degree, Institute of Parasitology Polish Academy of Sciences, Warszawa

Gawor J, Kornaś S, Charcenko V, Nowosad B, Skalska M (2006) Intestinal parasites and health problems in horses in different breeding systems. Medycyna Wet 62:331-334
Gundłach JL, Sadzikowski AB (2004) Parasitology and parasitoses of animals. PWRiL, Warszawa, pp 226-228

Gundłach JL, Sadzikowski AB, Tomczuk K, Studzińska MB (2004) Parasites of the alimentary tract of horses from the Lublin district in the light of coproscopic and gross anatomopathological examinations. Medycyna Wet 60:1089-1092

Kornaś S, Nowosad B, Skalska M (2004a) Intestinal parasite infections in horses from different types of environments. Medycyna Wet 60:853-856

Kornaś S, Nowosad B, Skalska M, Połoz T (2004b) Intestinal parasites infection of horses from riding clubs in Kraków area. Wiad Parazyt 50:323-327

Königová A, Várady M, Čorba J (2001) The prevalence of equine gastrointestinal parasites in the Slovak Republic. Helminthologia 38:211-214

Kuzmina TA, Kharchenko VA, Strovir AI, Dvojnos GM (2005) Analysis of the strongylid nematodes (Nematoda: Strongylidae) community after deworming of brood horses in Ukraine. Vet Parasitol 131:283-290

Lichtenfels JR, Kharchenko VA, Dvojnos GM (2003) Identification keys to strongylid nematode parasites of equids. At: http:// www.nas.gov.ua/iz/strong/classific.htm.

Lyons ET, Tolliever SC, Collins SS (2006) Prevalence of large endoparasites at necropsy in horses infected with population B small strongyles in a herd established in Kentucky in 1966. Parasitol Res 99:114-118

Nielsen MK, Peterson DS, Monrad J, Thamsborg SM, Olsen SN, Kaplan RM (2008) Detection and semi-quantification of Strongylus vulgaris DNA in equine faeces by real-time quantitative PCR. Int J Parasitol 38:443-453

Pereira JR, Vianna SSS (2006) Gastointestinal parasitic worms in equines in the Paraiba Valley, State of São Paulo, Brazil. Vet Parasitol 140:289-295

Schnieder T (2006) Veterinärmedizinische Parasitologie. Parey MVS Medizinverlage, Stuttgart

Sobieszewski K (1967) Parasitic nematodes of alimentary tract of horses in the Lublin Palatinate. Acta Parasit Pol 15:103-108

Theodoridis Y, Founta A, Georgoulakis I (1999) Gastrointestinal nematodes of equine in the region of Thessaloniki. J Hellenic Vet Med Soc 50:127-129

Traversa D, Iorio R, Klei TR, Kharchenko VA, Gawor J, Otranto D, Sparagano OAE (2007) New method for simultaneous speciesspecific identification of equine strongyles (Nematoda, Strongylida) by reverse line blot hybridization. J Clin Microbiol 45:2937-2942

Uslu U, Guclu F (2007) Prevalence of endoparasites in horses and donkeys in Turkey. Bull Vet Inst Pulawy 51:237-240 